\title{
Cutaneous Melanoma cM1c TNM Finding v7
}

National Cancer Institute

\section{Source}

National Cancer Institute. Cutaneous Melanoma CM1C TNM Finding v7. NCI Thesaurus. Code C88410.

Cutaneous melanoma with metastases to all other visceral sites associated with normal serum lactate dehydrogenase (LDH) or distant metastases to any site associated with an elevated serum LDH. (from AJCC 7th Ed.) 